Tomasz Stypka and Agnieszka Flaga- Maryanczyk

\title{
DEVELOPING THE EVALUATION CRITERIA FOR THE MUNICIPAL SOLID WASTE SYSTEMS - KRAKOW CASE STUDY
}

\author{
Politechnika Krakowska, Instytut Inzynierii CiepInej i Ochrony Powietrza \\ 24, Warszawska str., 31-155 Krakow, Poland \\ stypka@gmail.com
}

Received: December 09, 2009 / Revised: September 02, 2010 / Accepted: September 16, 2010

( ) Stypka T., Flaga-Maryanczyk A., 2010

\begin{abstract}
The article presents the methodology which can help the decision makers in evaluation of different municipal solid waste disposal systems. The results of the well known computer Integrated Waste Management model (IWM-1) are usually too fragmented to allow the final decision. The authors present the scientific background of the IWM-1 results integration. The results of the IWM-1 model analysis have been integrated into some specific categories that originate from the field of the Life Cycle Analysis (LCA). The authors propose 11 environmental categories plus the general ones calculated by the IWM-1 model. The presented categories describe the environmental impact of the analyzed system and are far easier to identify and understand by the public and by the decision makers.

The developed methodology has been applied for the City of Krakow. The authors analyze two Krakow municipal solid waste disposal systems. The first system has been in operation for the last few years. The waste is collected and disposed at the landfill site while recycling and composting are implemented only in a limited scale. The second system presents the potential ultimate solid waste option for Krakow, where the waste is sorted extensively, then a significant part of organic fraction is composted, and the rest of the waste goes to the incinerator. The presented analysis compares these two systems. The authors use the results from the IWM-1 models for both systems as the input data to calculate the proposed impact categories. The final outcome is presented as graphs with the detail description of each stage of generation.
\end{abstract}

Keywords: regional municipal solid waste management modeling, LCA.

\section{Introduction}

The decisions in the area of municipal solid waste management are not very intensive enough, but also difficult from both environmental and social points of view. There is a need to develop, master and implement a simple, but reliable tool that would help the decision makers in the analytical process. There are several mathematical models that can help the decision makers in their tasks though the main decision variable in such models remains expensive. The environmental elements (the recycling schemes) have appeared in the models beginning in 1980s [4, 8]. Another group of models includes the environmental factors in the form of constrains of the economic models [3]. Some of the models conduct the Life Cycle Analysis (LCA) of the waste disposal system while others focus only on different environmental elements such as noise or traffic [3] or $\mathrm{CO}_{2}$ emissions from vehicles [13].

The uncertainty of the parameters is also an important criterion while dividing models into different categories. Deterministic models such as linear programming (LP), mixed-integer programming (MIP), dynamic programming (DP) and multi-objective programming are used to analyze the problems where there is an assumption of the parameters' certainty. To account for uncertainty, the models use the probability theory as well as the fuzzy and grey system theory.

The models can estimate waste generation predictions as well as facility sites selection and facility capacity expansion or operation. Similarly, other models can determine vehicle routing, manpower assignment, overall system operation, system scheduling, waste flow, environmental performance or technology selection [2].

A separate group of computer models applies the concept of Life Cycle Analysis (LCA). The examples of such models are: the US-EPA [1], Integrated Waste Model IWM [14], MIMES/Waste [12], ORWARE [6], ISWM tool Canada, and WISARD [14]. These models are readily available applications but in practice most models are still in the development or upgrading stages, with the exception of the IWM model. The ORWARE and MIMES/Waste models are very difficult to use because of their platform 
and complexity. Therefore, the potential user is left with the IWM models. At present there are two versions of the IWM model: IWM-1 and IWM-2. The two versions differ not only with the applied platform, (IWM-1 is an Excel spreadsheet while the IWM-2 is a stand-alone program), but also the IWM-2 produces more accurate data and has a more elaborate thermal treatment section. The choice of the platform results in the level of transparency of the two IWM models. IWM-1 is a transparent model and the experienced user can temper it with the coefficients, adjusting them to the local conditions, while the IWM-2 works in a closed environment. The lack of transparency inherent in the IWM-2 was the reason for using the IWM-1 in the presented project. The results of the IWM models are very fragmented hence not useful for the decision makers. Two methods of the results integration are presented. Both methods were applied to compare the MSWM systems in Krakow. Krakow develops its new system expanding the traditional one, based on landfilling and limited sorting and composting facilities. After expansion, the waste will undergo the intensive sorting at the source, then extensive composting and finally the restwaste would be incinerated. The landfill is to be used only for disposing the ash from the incinerator.

\section{Experimental}

\subsection{IW M-1 Integration Method}

Generally, the method of the IWM integration is based on application of one or even two stages of Life Cycle Analysis: Impact Assessment and Interpretation. To calculate these indicators the authors used the methodology which was described in detail in other articles $[10,11]$. The assumption was to use the maximum possible number of categories, which could be calculated based on the IWM-1 results. The list of the selected categories is presented in Table 1.

Indicators for different impact categories were selected based on the literature [7]. Unfortunately, not all recommended impact categories can be directly calculated from Table's results. For example, this software gives no information about a new land designated annually for waste disposal, extracted raw materials or energy sources.

Table 1

Selected categories of the Life Cycle Impact Assessment

\begin{tabular}{|c|c|c|}
\hline Impact categories & Characterisation factor & Unit \\
\hline \multicolumn{3}{|c|}{ Baseline categories } \\
\hline $\begin{array}{l}\text { Depletion of abiotic } \\
\text { resources }\end{array}$ & Abiotic depletion potential (ADP) & $\mathrm{kg}$ (antimony eq.) \\
\hline Climate change & Global Warming Potential (GWP 100) & $\mathrm{kg}$ (carbon dioxide eq.) \\
\hline Human toxicity & Human toxicity potential (HTP 100) & kg (1,4-dichlorobenzene eq.) \\
\hline $\begin{array}{l}\text { Ecotoxicity: fresh } \\
\text { water aquatic } \\
\text { ecotoxicity }\end{array}$ & $\begin{array}{l}\text { Freshwater aquatic ecotoxicity potential } \\
\text { (FAETP 100) }\end{array}$ & $\begin{array}{l}\mathrm{kg}(1,4- \\
\text { dichlorobenzene eq. })\end{array}$ \\
\hline $\begin{array}{l}\text { Ecotoxicity: } \\
\text { terrestrial } \\
\text { ecotoxicity }\end{array}$ & Terrestrial ecotoxicity potential (TETP 100) & kg (1,4-dichlorobenzene eq.) \\
\hline $\begin{array}{l}\text { Photo-oxidant } \\
\text { formation }\end{array}$ & Photochemical ozone creation potential (POCP) & kg (ethylene eq.) \\
\hline Acidification & Acidification potential (AP) & kg (SO2 eq.) \\
\hline Eutrophication & Eutrophication potential (EP) & kg (PO43- eq.) \\
\hline $\begin{array}{l}\text { Stratospheric ozone } \\
\text { depletion }\end{array}$ & Ozone depletion potential (ODP steady state) & kg (CFC-11 eq.) \\
\hline Land competition & Land use & $\mathrm{m} 2$ year \\
\hline \multicolumn{3}{|c|}{ Other impact categories } \\
\hline $\begin{array}{l}\text { Odour malodorous } \\
\text { air }\end{array}$ & Reciprocal of odour threshold value (1/OTV) & m 3 (air) \\
\hline
\end{tabular}




\subsection{Description of the Systems}

The analysis compares the Krakow waste disposal system, operated by the city in 2001, with the new prospective system employing waste incineration. The detailed description of both systems can be found in the dissertation written by Kopacz [9].

In 2001 the city had 150 recycling material banks. The banks were designed for collection of metal, paper, PET bottles, and glass. Additionally, the city had the system of ,bring and earn” collection points, where both city dwellers and small business ventures could dispose their waste, suitable for recycling. At that time, the city had the composting facility with the throughput of 6000 tons per year. The facility treated the waste from the city green areas, farmers' markets, food processing and tobacco industry. The green waste coming from industry was excluded from the analysis. The charity organizations run the system of collection points for the textile waste.

The new system assumes commissioning the incinerator with annual capacity of 200000 tons of waste. Additionally, the number of collection banks will be increased up to 450, and a new Material Recovery Facility ready to handle 20000 tons of recyclables plus two composting facilities for 6000 and 9000 tons of green waste will be constructed. In some parts of the town the implementation of the ,wet" and ,dry" waste collection systems is planned.

\section{Results and Discussion}

The IWM-1 model offers the energy balance for two analyzed scenarios (Fig. 1). The graph shows that in both scenarios the collection stage is the most energy consuming stage of waste disposal. Once the incinerator has been build, it becomes the significant source of energy. On the other hand, at present the landfill is also the significant source of energy due to landfill gas (LFG) combustion. The waste incineration generates about four times more energy than landfill gas combustion. If the waste heat, from the LFG powered co-generation units was also utilized, the energy balance would not be so favorable for incineration. The total energy balance is negative for the present system, because the energy generated and utilized in the landfill covers only half of the energy needed at the collection stage. The future system becomes the net energy producer since the incinerator generates far more energy than is needed at the collection stage and at the sorting and composting facilities.

Both scenarios provide significant energy savings thanks to the recycling programs that can cut down energy consumption in the paper, plastic and glass producing

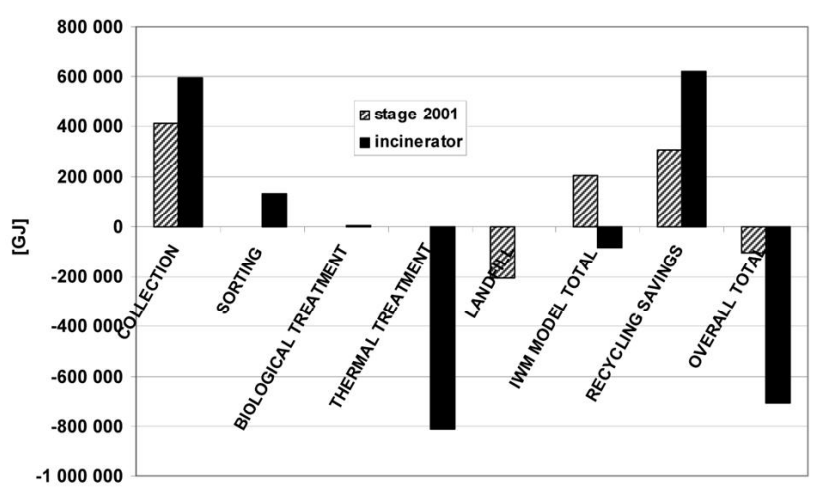

Fig. 1. Energy balance for two Krakow MSWSs: present stage $v s$. incinerator

facilities. Since the future system is much bigger it consumes more energy at the collection stage, however it also saves more energy in the paper plastic and glass producing facilities. Looking from the LCA perspective that takes into consideration the savings of the energy at the raw material production stage, both systems are net energy producers, but the total balance in the future system is seven times bigger.

The main reason for introducing the waste incineration is to reduce waste volume and furthermore to prolong the landfill's lifespan. The IWM-1 model can estimate the efficiency of this process, showing the total amount of waste deposited at the landfill, for two scenarios. For the scenario with the incinerator and a developed recycling program the IWM-1 estimates that the amount of waste will drop four times in terms of both volume and mass load, in comparison with the present model.

Unfortunately, information about the specific emissions into water and air is not customized for the direct application at the stage of the decision making. It has to be further integrated and processed to become useful for the decision makers. The results of such integration and processing are presented in the following part of the article.

\subsection{Abiotic Depletion}

This category describes the depletion rate of the natural Earth resources (including the energy resources) such as oil, metal ores and wind potential. The depletion rate is measured in comparison with the remaining resources. The results of the Krakow analysis are presented in Fig. 2.

The analysis shows that from the abiotic depletion point of view the second scenario is far worse than the present solution. During the thermal treatment different elements and compounds are released into the environment in small portions. Those emissions are not necessarily dangerous to the environment, but the elements and 
compounds are inevitably lost. Mercury emission has the biggest impact on abiotic depletion index. It makes up $41 \%$ of the index at the combustion stage and $35 \%$ of the index calculated for the entire IWM model. When the waste is stored in the landfill, mercury is not transformed into the LFG, hence it is not released into the environment. Additionally, burning of LFG reduces the demand for conventional production of energy and this way gives „small savings" in sulfur oxides, which would be released from the conventional power plants, if this energy had to be produced there.

Resource savings obtained thanks to the extensive recycling planned in the incineration scenario do not change the overall perspective: the present scenario remains superior to the incineration scenario from the abiotic depletion point of view. A significant improvement of this index can be obtained by introduction the intensive collection of separated source and household hazardous waste (HHW). This is particularly important now, when there is an promotion of fluorescent lamps, which are energy efficient, but contain mercury. Such used lamps have to be collected separately and transported to the manufactures for mercury recovery.

\subsection{Global Warming - Climate Change}

The comprehensive presentation of the obtained results of the analysis is shown in Fig. 3. Incineration and landfilling are two techniques of waste disposal with the strongest impact on the climate change. Collection makes up only $10 \%$ of the entire index. Incineration and landfilling are associated with methane and carbon dioxide generation. Specially methane (generated only in the landfill) is 21 more powerful than carbon dioxide and needs special attention. The part of methane is captured and utilized in the CHP units. The product of LFG utilization is carbon dioxide and that makes landfills with LFG utilization equally

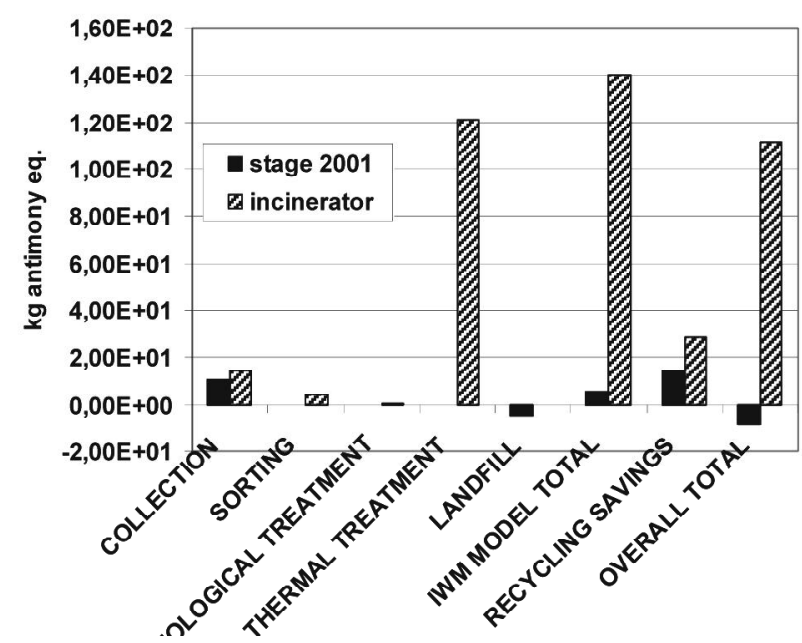

Fig. 2. Abiotic depletion for two Krakow MSW systems damaging for the climate change as incineration. Unfortunately the part of the LFG is released directly into atmosphere increasing the relative global warming impact of the landfill. The total impact of the landfill on the climate change is $50 \%$ higher than the impact of the incinerator. Recycling in both scenarios generates the minimal profits for the global environment and therefore the present waste disposal scenario has more deteriorating impact on the global climate than the new proposal.

Recycling has rather a small impact on the global warming index because the boarders of the analyzed system are drawn in such a way that although the energy savings are calculated by the model (Fig. 1), the emissions associated with these savings are already beyond the scope of the analysis. As a result, the total impact of the two analyzed scenarios on the climate change, conducted from the local and LCA perspective are the same. The present system of waste disposal discharges annually the global environment $57000 \mathrm{Mg}$ of carbon dioxide more, than the new system.

\subsection{Human Toxicity}

This index covers the impact of the toxic substances present in the natural environment on the human health. However, it does not estimate the impact of these substances if emitted at the work place. The toxicity of each compound is measured by the coefficient called Human Toxicity Potential HTP $_{\mathrm{i}}$. The $\mathrm{HTP}_{\mathrm{i}}$ value describes the type of environment into which a compound is emitted, its pathway before reaching the human being and then inside the human body, as well as its toxicity depending on the pathway it takes within the human body. The HTP index measures the toxic impact of the analyzed substance on a human being in comparison with the 1,4-dichlorobenzen. The basic 100 year long perspective of influence was assumed in the analysis.

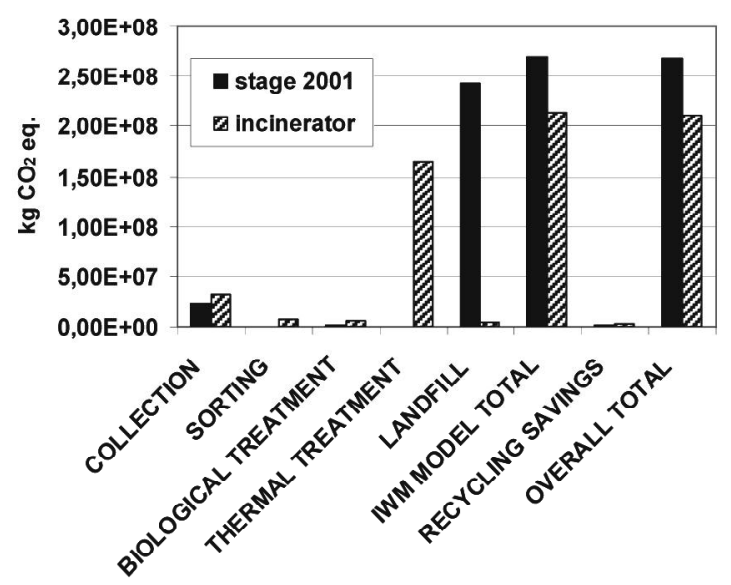

Fig. 3. Climate change for two Krakow MSW systems 


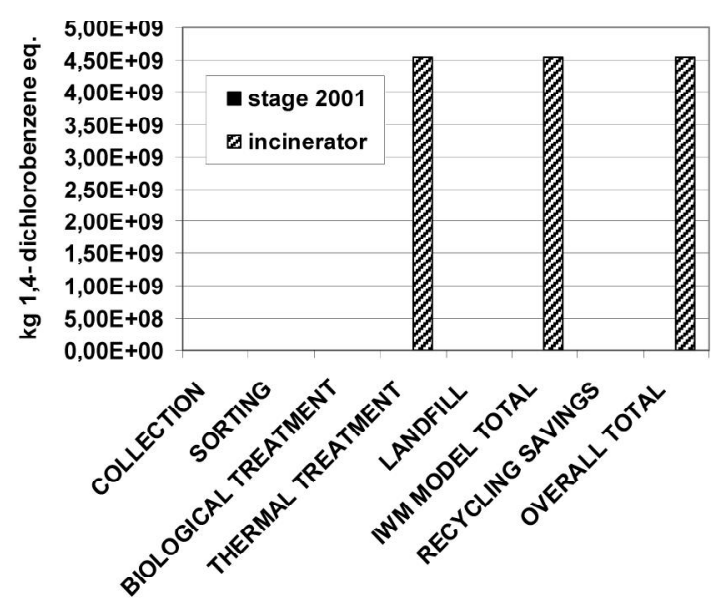

Fig. 4. Human Toxicity Impact of two Krakow MSWM systems

Fig. 4 clearly indicates that the scenario with incineration has a negative impact on the human health. The detailed analysis of the result confirms that although all stages of the waste disposal system have a negative impact on human body, incineration is 10000 times more powerful than the other ones. The impact of the landfilling is comparable with the collection stage. The main reason for such negative impact of the incineration is not emissions of commonly feared dioxins and furans but rather emission of chromium compounds.

The authors assumed that emission of chromium calculated by the IWM-1 model takes place in the form of chromium VI, which is the most toxic form of chromium for humans. Dioxins are five hundred times more toxic then a chromium, but their emission is only $0.1 \mathrm{~g} /$ year while the emission of chromium is estimated at the level of $1277 \mathrm{~kg} /$ year. This emission, in terms of human toxicity, is equal to the emission of $4.3 \cdot 10^{9} \mathrm{~kg}$ of 1,4 - dichlorobenzene eq. Similar to the mercury emission from incineration, which increases the abiotic depletion index, the source separation and reduction of chromium containing products seems the best option to address the issue of toxicity hazard from the incinerator.

Recycling reduces the toxicity of waste disposal to the humans. In the scenario 2001, recycling reduces the toxicity by $1 / 3$, while in the second scenario the development of the more advanced recycling program generates twice as much toxic reduction. Unfortunately, the negative impact of incineration is 10000 more significant and can not be neutralized by the progress in recycling.

The authors assumed that chromium was emitted in its most toxic form, chromium VI. However, even if it is assumed that less dangerous chromium III is emitted and the absolute values of the calculated HTP are lower

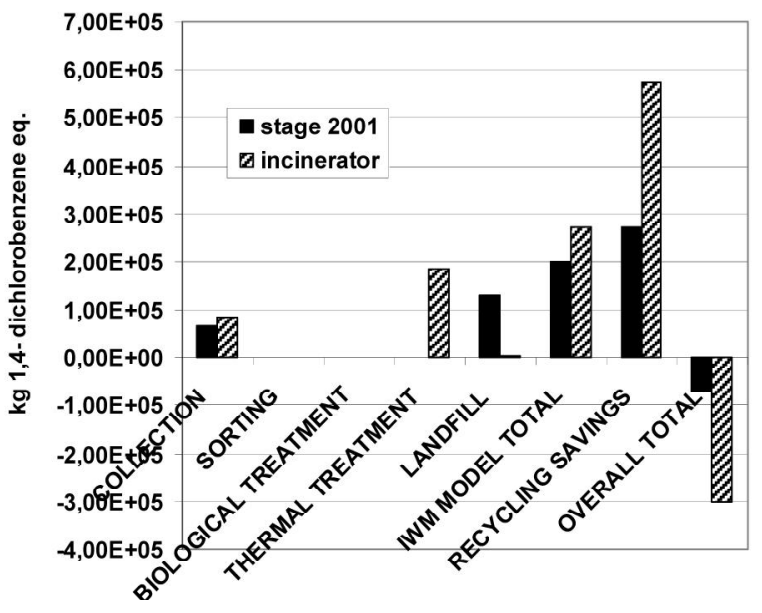

Fig. 5. Freshwater Aquatic Ecotoxicity of two Krakow MSWM systems

but the character of the graphs will not be changed. No matter which form of chromium is taken into the analysis the scenario with the waste incineration turns out to be more dangerous for human beings. If it is assumed that chromium is emitted as chromium III the emissions of nickel and arsenic become more important in the HTP index. The emissions of dioxins still have not significant impact on the HTP index value.

\subsection{Freshwater Aquatic Ecotoxicity}

It is one of many categories describing the impact on the natural environment (ecotoxicity). The category covers the impact on the fresh water only, but not on the sediment. The impact is measured by 1,4-dichlorobenzene eq. in 100 years perspective. The FAETP index measures the toxicity of the given emission (in reference to dichlorobenzene) in the fresh water environment (medium into which the emission took place) and efficiency of substance's migration from the medium into it was emitted into the water environment. The category calculates the harmful impact on the water environment only, even if the emission took place into the air or soil.

Fig. 5 presents the impact of the solid waste disposal systems on the fresh water environment. Both scenarios show the negative effect but the incinerator's impact is the strongest, even stronger than landfilling. The more thorough analysis shows that air emissions play here the more important role than wastewater: the former one makes up $99.9 \%$ of the total FAET value while the latter one only $0.1 \%$ of the FAET. Hydrogen fluoride (HF) is the biggest contributor to the FAET and not because of its high toxicity but because of the emission volume half of water environment toxicity is attributed to its presence in water. Copper emissions also significantly contribute to 
the FAET making up $21 \%$ of the whole index; emission of nickel contributes to the FAET by $19 \%$.

Phenol emissions observed at the collection stage have a negative impact as well. Phenol is emitted into atmosphere during production of the diesel oil needed for the waste transporting trucks. According to the IWM-1 data, the production of 1000 liters of diesel oil is accompanied by emission of 36 grams of phenol.

Landfills affect the aquatic environment because of the leachate production. Leachate makes up $99 \%$ of the FAET while the air emissions of the landfill gas make up only $1 \%$ of the FEAT total value. The most toxic compound in leachete is AOX (AOX -absorbable chlorinated organics; the equivalent amount of chlorine, bromine and iodine contained in organic compounds in water or wastewater, expressed as chloride).

Theoretically the leachate is collected and treated, but in real life the part of the leachate is released directly into ground and surface waters. IWM- 1 model assumes that $70 \%$ of the leachate is collected, and the rest is released directly into the water environment. It is estimated that the directly released leachate contaminates water environment with $22 \mathrm{~kg}$ of AOX per year. AOX makes up $89 \%$ of FEAT even the FEATP for AOX is very much comparable with mercury, cadmium, nickel, and copper. The final disposal of the ashes from the waste incineration does not have any significant impact on the water environment.

Recycling and its development have a significant impact on the value of the FEAT. The direct emissions into the water make up $99.8 \%$ of the total value of the indicator, with AOX playing the main role. The source of these savings is lower emission of AOX obtained thanks to the reduction of paper production from the virgin material. It is estimated that thanks to recycling programs the production of paper from the virgin material would drop by $44090 \mathrm{Mg}$ and reduction of AOX emission from the paper mills by $110 \mathrm{~kg}$. As the value of FAETP ${ }_{\mathrm{AOX}}$ is high $\left(5.2 \cdot 10^{3} \mathrm{~kg} \mathrm{1,4-dichlorobenzene} \mathrm{eq.)} \mathrm{such} \mathrm{drop} \mathrm{in}\right.$ paper production equals to the reduction of $5.73 \cdot 10^{5} \mathrm{~kg}$ 1,4-dichlorobenzene eq. emission into the aquatic environment. This makes almost $100 \%$ of the index value. Phenol is the second important pollutant responsible for the aquatic toxicity. Recycling reduces the phenol emission by $1.17 \cdot 10^{2} \mathrm{~kg} 1,4$-dichlorobenzene eq., and that makes up only $0.02 \%$ of the whole index.

Generally, a well organized system of waste management has a significant impact on the water system quality. The analyzed new scenario of the waste management has the less damaging impact on the aquatic systems thanks to the more advanced recycling programs, because the incinerator itself affects the aquatic system more badly than the present landfill. Increasing the efficiency of the leachate recovery has also a positive effect on the aquatic environment, if measured by the FAET index.

\subsection{Terrestrial Ecotoxicity}

The next index is the terrestrial ecotoxicity. It is measured similarly to aquatic ecotoxicity and expressed with the same units. Even though two indexes are measured in the similar way and have the same units they cannot be directly compared or added. All these indexes are the subject of the "unofficial critique" from the LCA community. The extra precaution in the index's interpretation is recommended particularly when the main contributions to the index are chromium $(\mathrm{Cr})$ and beryllium (Be) [7].

Fig. 6 presents the terrestrial ecotoxicity of the two solid waste disposal scenarios. Their impact on soil at different stages of a waste disposal system is very similar to the one observed for the Human Toxicity Impact Index (Fig. 4). The waste incineration scenario causes 10000 times bigger damage to the soil than the present system. In practical terms it means that the present system has an insignificantly small impact on the land, if compared with the incineration.

The incinerator affects the soil by flue gases and by emission of heavy metals, in particular. The IWM-1 model estimates that every year the incinerator emits $101 \mathrm{~kg}$ of mercury $(\mathrm{Hg}), 1280 \mathrm{~kg}$ of chromium $(\mathrm{Cr})$, $507 \mathrm{~kg}$ of arsenic (As) and $507 \mathrm{~kg}$ of nickel (Ni) to the air. All these emissions have the negative impact on the soil, but mercury contributes $89 \%$ into the Terrestial Ecotoxicity index (TET). Chromium contributes to this index only $7 \%$ while arsenic $2 \%$ and nickel only $1 \%$.

Analysis of the Terrestrial Ecotoxicity impact of the present scenario of waste disposal produces some interesting conclusions. The existing system has a negative impact on thesoil and the total value of TET equals to $8.56 \mathrm{~kg}$ 1,4-dichlorobenzene eq. Recycling has a very positive impact, if measured by TET. Thanks to paper recycling the mercury emission is reduced by $0.0623 \mathrm{~kg}$ of mercury/ year (equivalent to $197 \mathrm{~kg}$ of 1,4-dichlorobenzene), which is twenty times higher than the emission from the present system.

If the recycling systems are more efficient the avoided emissions are proportionally larger.

\subsection{Photochemical Smog}

Photochemical smog is a product of chemical reaction of some air pollutants under solar radiation. One of the reaction products is ozone. Ozone is harmful not only for humans but also for the ecosystem. Human health, manmade environment, natural environment, and natural resources require protection against ozone. Smog is created in the troposphere as a product of photo-oxidation of volatile organic compounds (VOC) and carbon monoxide (CO) in the presence of nitrogen oxides $\left(\mathrm{NO}_{\mathrm{x}}\right)$. Ozone $\left(\mathrm{O}_{3}\right)$ and PAN (penoxyacetylnitrate) are ones of many end products of these reactions. 


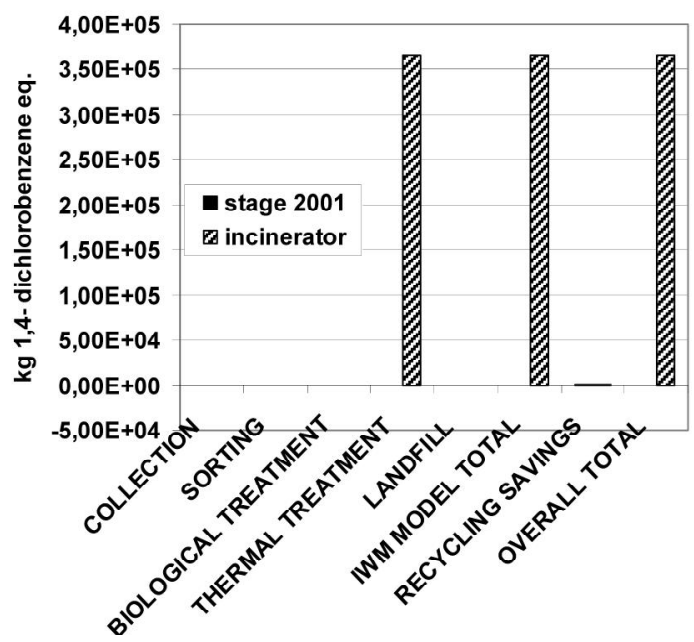

Fig. 6. Terrestrial ecotoxicity of two Krakow MSWM systems

A photochemical smog index is measured in the same way as the other indexes, by multiplying the Photochemical Ozone Creation Potentials (POCP) of different complexes by the mass of this complex emission. The total value of the index is the sum of photochemical smog indexes of different emissions. The unit of this category is $\mathrm{kg}$ of ethylene eq. (Fig. 7).

The present waste disposal system has a far more negative impact on environment, if measured by Photochemical Ozone Creation, than the incineration system. The smog creating compounds are created both at the level of waste collection and landfilling. The value of the POC at the collection stage is $67 \%$ higher than that at the landfill. Smog at the collection stage is created by such emissions like hydrocarbons, nitrogen oxides, sulfur oxides, and carbon monoxide. These compounds are byproducts of diesel oil combustion and plastic waste containers production. At the landfill a site smog is generated as a result of emission of the landfill gas, methane in particular. On the other hand, electricity generated in the LFG replaces the one generated at conventional power plants, which results in reduction of sulfur oxides, nitrogen oxides and reduction of the POC index at the landfilling stage. At the final balance of these two processes, the landfill generates $55300 \mathrm{~kg}$ of ethylene eq. The energy generation from the incinerator is much higher, resulting in larger avoided emission, which makes the POC even negative at the incineration stage.

Development of the recycling stage also reduces the emission of the smog creating compounds. In the second analyzed scenario, with a far more advanced recycling system, the emission of the smog creating substances is reduced almost by half. In conclusion, from the LCA point of view, the new scenario of waste management reduces the total smog creation while the present scenario has a negative impact on the air quality.

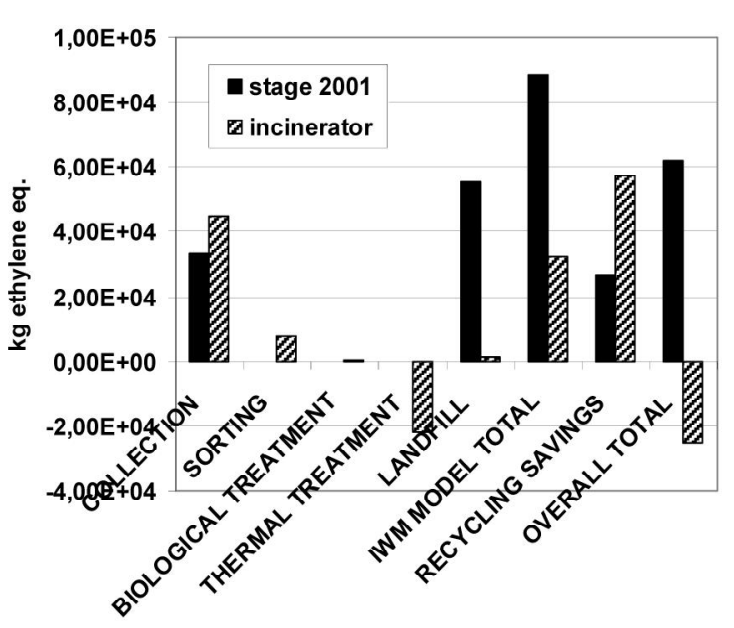

Fig. 7. Smog creation by two Krakow MSWM systems

On the other hand, from the local perspective, both systems enhance smog creation, though the incinerator scenario does it less significantly.

\subsection{Acidification}

Acidifying pollutants emitted into the environment, have impacts on soil, groundwater, surface waters, biological organisms, ecosystems, and materials. The major acidifying pollutants are $\mathrm{SO}_{2}, \mathrm{NO}_{x}$ and $\mathrm{NH}_{\mathrm{x}}$. Areas of protection are the natural environment, the man-made environment, human heath and natural resources.

The acidification is measured, as in all other categories, by multiplying the emissions by their Acidificiation Potential $\mathrm{AP}_{\mathrm{i}}$ of each pollutant, and then by adding the products. The Acidification Potential of each pollutant compares the impact of emission of $1 \mathrm{~kg}$ of this substance with the emission of $1 \mathrm{~kg}$ of sulfur dioxide $\left(\mathrm{SO}_{2}\right)$. The value of AP represents the maximum potential of each substance to cause the acidic deposits, but its real value can be smaller and depends heavily on the local conditions. In the analyzed case, it was assumed that the acid deposits will affect the City of Krakow, which is sensitive to such impacts as a place of a very high material and cultural value (lime stone historic buildings, steel constructions). That is why the value of the AP was not reduced by any reduction coefficients. The obtained results are presented in Fig. 8.

The acidification problem appears at all stages of waste disposal system. It is caused by diesel oil burning during the waste collection as well as the emissions during the waste incineration. The landfill equipped with the LFG extraction system used to produce electricity is a sink for the acidic emissions because it generates far less acidic emissions than are generated at the conventional power plants. 


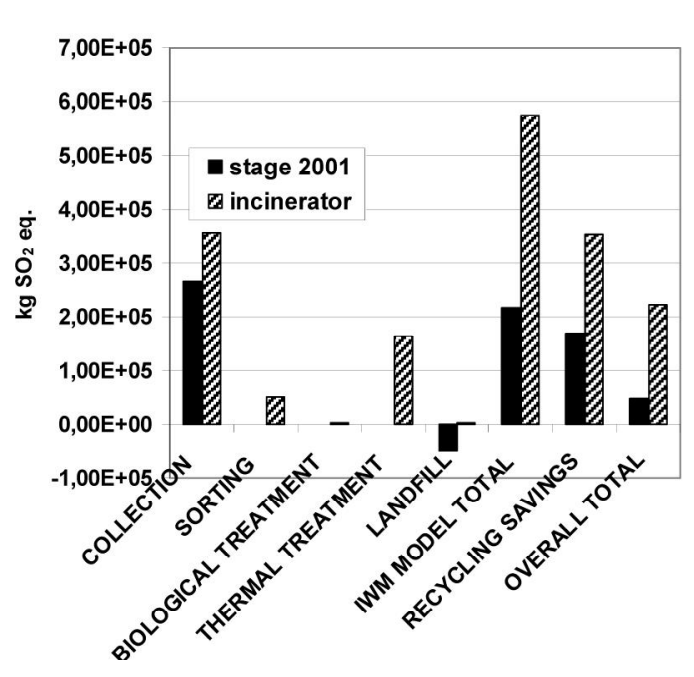

Fig. 8. Acid rain creation by two Krakow MSWM systems

The acidic emission during the waste incineration is already reduced by the amount of avoided emission of the electricity generated at the conventional power plants. $54 \%$ of the acidification index at the combustion stage is caused by the emissions of sulfur dioxide. The observed "savings" at the recycling stage are mainly caused by the reduction of the energy demand in production of plastic, paper, and metal from the recycling materials. This reduction includes the energy consumption needed for transportation of the recycling material to the processing facilities. The development of the recycling program (the second scenario) results in bigger savings during the recycling stage, but it does not change the total picture. The present system of waste disposal causes less damage attributed to acidification.

\subsection{Eutrophication}

This category covers all potential effects of excessively high levels of macronutrients in the environment; the most important ones include nitrogen $(\mathrm{N})$ and phosphorus (P). Nutrient enrichment may cause an undesirable shift in species composition and excessive biomass production in both aquatic and terrestrial ecosystems. In addition, high nutrient concentrations can also make surface water unacceptable for drinking. In aquatic ecosystems a high level of biomass production may result in oxygen depletion (measured as BOD). As emissions of degradable organics have a similar impact, such emissions are also treated under the impact category "eutrophication". The value of this category is measured in comparison with the eutrophication potential of $1 \mathrm{~kg}$ of $\mathrm{PO}_{4}^{3-}\left(\mathrm{EP}_{\mathrm{i}}\right)$. The results for the Krakow case are presented in Fig. 9.

Waste collection is the main stage where euthorpication stimulating compounds are generated. Eutrophication is caused by the emission of nitrogen oxides

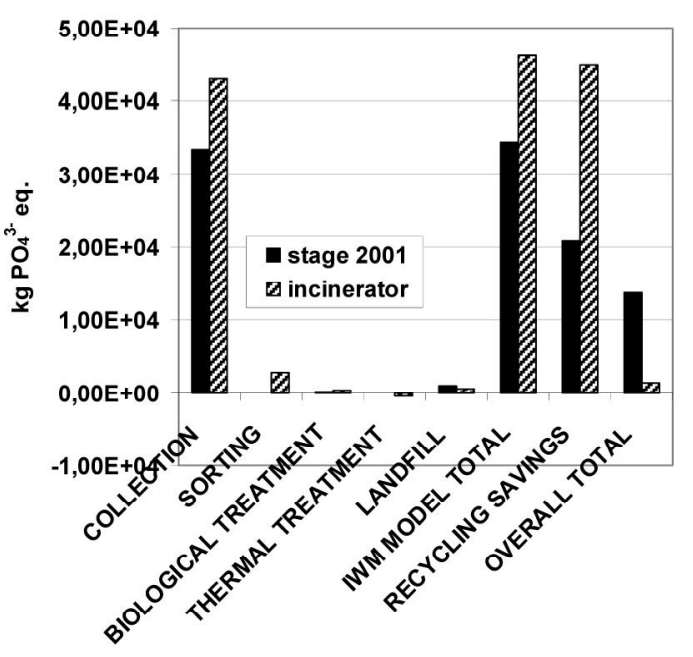

Fig. 9. Eutrophication caused by two Krakow MSWM systems

generated during the diesel oil combustion in trucks, collecting both recyclables and mixed wastes. The IWM-1 model estimates that at the present waste disposal scenario a collection stage generates $2.57 \cdot 10^{5} \mathrm{~kg}$ of nitrogen oxides/ year; it is $97 \%$ of the total value of the eutrophication index.

Recycling reduces the total value of eutrophication both into the air and water. In the air emissions the positive effects are obtained thanks to the reduction of nitrogen oxides emissions, while reduction of BOD and TOD are responsible for the effects in water emissions. The positive effects come from different emissions, which take place at the production phase where either virgin or recyclable materials may be used. The emissions from transportation of the recyclables into processing plant are also included in calculations. The expected savings are significant. In the incinerator scenario, the advanced recycling program offsets all the negative impacts of the collection. From the eutrophication point of view, the incinerator scenario turns out to be more friendly toward the environment, because the incinerator does not show a harmful impact on the environment and the advanced recycling system fully offsets the negative impact of the collection. In the present system the less efficient recycling does not totally offsets the collection and the total impact of the system is slightly negative.

\subsection{Odour - Other Impact Category}

Odour becomes a problem when a given concentration of odorous substances is experienced as unpleasant. Whether an odour is experienced as stench will depend on the sensitivity of the particular individual exposed to it. Though, above a certain emission level every individual will experience in such a way. In this case the area of protection is human health. 
Odour may be defined as the observed difference between a sample of clean air and a sample of contaminated air. The concentration at which such a difference occurs varies from substance to substance, and depends on the physical and chemical properties of the substance. The odour threshold value of a substance is defined as the concentration under defined standard conditions, when $50 \%$ of a representative population sample can just detect the difference between a sample of an air/substance mixture and a clean air sample. Odour can be measured fairly objectively while odour nuisance is more a matter of individual sensitivity. The nuisance associated with odour from each substance is measured by dividing the emissions of potentially malodorous substances by the odour threshold value. The total value of odour nuisance is the sum of all malodorous substances and it indicates how much air has to be added to reach the threshold value. The obtained results for Krakow analysis are presented in Fig. 10.

IWM-1 estimates only three emissions of maladorous substances. Never-the-less the obtained results are interesting and confirm the widespread expectations that the scenario with the waste incineration reduces the odour problem. The landfill is the main source of odour. If the model calculated all the aromatic substances emitted to the air with the LFG the description of two scenarios would be even gloomier. Waste incineration reduces the odour nuisance approximately by 100 times. This is mainly caused by the reduced emission of hydrogen sulfide $\left(\mathrm{H}_{2} \mathrm{~S}\right)$.

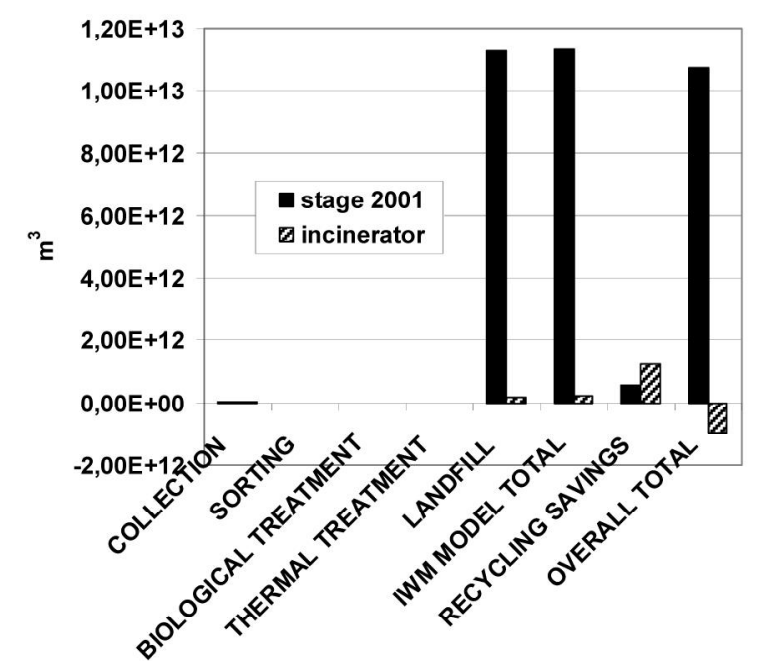

Fig. 10. Odour emissions from two Krakow MSWM systems

Recycling generates some avoided odour emissions mainly by the reduction of hydrogen sulfide during the paper production. The IWM-1 assumes that reduction of paper production from the virgin material results in the reduction of 12 grams of hydrogen sulfide. In the incinerator scenario the avoided emissions are bigger than the emissions from all stages of waste disposal. From the LCA point of view, the scenario with the incinerator reduces the total level of odours. The problem with such approach is that odour is a local problem and for the people living near one disposal facility the potential reduction of odour at the other location is not the argument. Generally the waste incineration reduces the odour problems by 45 times, in comparison with the present system.

\section{Conclusions}

The presented method of aggregating the results of the IWM-1 model allows to compare different municipal solid waste disposal scenarios. However, the obtained results are not obvious in the presented case study, where two Krakow systems were compared. The present system based on landfilling turned out to be superior when the following criteria were analysed: abiotic depletion, human toxicity, freshwater aquatic ecotoxicity, terrestrial ecotoxicity, acidification, and eutrophication. The second scenario, with advanced waste sorting and incineration, turned out to be better in categories of energy consumption, climate change, photochemical smog creation and odour creation. More detailed analysis of different stages of waste disposal for two compared waste disposal systems is recommended.

The obtained results still do not give a straight answer about the superiority of one specific scenario. The application of the multicriteria analysis seems to be the next step in finding the ultimate solution.

\section{Acknowledgements}

The presentation of the research result was possible thanks to the financial assistance from the Swedish Institute.

\section{References}

[1] Barlaz M., Ranjithan R., Weitz K. and Nishtala S.: LifeCycle Study of Municipal Solid Waste Management, System Description. US Environmental Protection Agency, USA 1995. [2] Bjorklund A.: Licentiate Thesis. Stockholm University of Technology, 1998.

[3] Chang N., Shoemaker C. and Schuler R.: Waste Mgmt. \& Research, 1996, 14, 463.

[4] Clapham W.: Ohio J. of Sci., 1986, 86, 189.

[5] den Boer J., den Boer E. and Jager J.: VII Miedzynarodowe Forum Gospodarki Odpadami, Kalisz 2007, 465.

[6] Eriksson O., Frostell B., Bjorklund A. et al.: Resources, Conservation and Recycling, 2002, 36, 287.

[7] Guinee J.: Handbook on Life Cycle Assessment Operational Guide to the ISO Standards. Kluwer Academic Publishers 2002.

[8] Jenkins L.: Mgmt Science, 1982, 28, 1270. 
[9] Kopacz K.: Master Thesis. Dept. of Environmental Engineering, Politechnika Krakowska 2003.

[10] Stypka T.: Proc. of Polish-Swedish Seminar, Krakyw 2005. [11] Stypka T. and Flaga A.: VII Мікdzynarodowe Forum Gospodarki Odpadami Kalisz 2007, 435.

[12] Sundberg J.: Workshop on LCA and treatment of solid waste. Stockholm, Sweden, 1995, 252.

[13] Wang F., Richardson A. and Roddick F.: Computers, Environment and Urban Systems, 1988, 20, 233.

[14] White P., Franke M. and Hindle P.: Integrated Solid Waste Management - a Lifecycle Inventory. Blackie Academic \& Professional 1997.

\section{РОЗРОБЛЕННЯ КРИТЕРІЮ ОЦІНЮВАННЯ МУНЩЦИПАЛЬНИХ СИСТЕМ ВИДАЛЕННЯ ТВЕРДИХ ПОБУТОВИХ ВІДХОДІВ НА ПРИКЛАДІ КРАКОВА}

Анотація. Наведено методику, за допомогою якої проводиться очінювання різних муніципальних систем твердих побутових відходів. Результати відомої комп'ютерноі комплексної моделі управління відходами (IWM-1), як правило, $\epsilon$ занадто фрагментарними для прийняття остаточного рішення. Представлені наукові основи інтегрування результатів IWM-1. Результати аналізу моделі IWM-1 інтегровані в деякі специфічні категорії, щзо виходять з області аналізу життєвого цчиклу (АЖЦ). Запропоновано 11 екологічних категорій плюс одна загальна, розрахована за IWM-1 моделлю. Приведені категорії описують вплив проаналізованої системи на довкілля і є більш доступними для розуміння громадськістю та особами, щзо приймають рішення. Показано як розроблену методику застосовано на прикладі м. Кракова. Проаналізовано дві Краківські системи видалення твердих побутових відходів. Перша система перебуває в експлуатацї̈ протягом останніх кількох років. Відходи збираються і транспортуються на звалище, в той час як утилізація і компостування здійснюються лише в обмежених маситабах. Друга система представляє альтернативний варіант длям. Кракова, вякомувідходи екстенсивно сортуються, тому значна частина органічної частини компостується, а решта спалюється. Представлений аналіз порівнює ціі дві системи. Результати моделі IWM-1 для обох систем використані як вихідні дані для розрахунку запропонованих категорій впливу. Остаточні результати представлені у вигляді графіків, з детальним описом кожної стадї формування.

Ключові слова: моделювання управління муніциипальними твердими побутовими відходами, АЖЦ. 